\title{
Universal Basic Education (U.B.E) Programme in Nigeria: Personnel and Infrastructural Assessment in Birnin Kebbi Local Government Area
}

\author{
Tyoakaa, Lazarus Mvendaga \\ Government Science \& Technical College, P.M.B. 1001,Bunza, Kebbi State-Nigeria.
}

\begin{abstract}
This study was set to assess the level of readiness of primary schools in Birnin Kebbi local government area of Kebbi state-Nigeria, in terms of Personnel and infrastructure, in the implementation of the universal basic education programme of the Federal government. The study adopted a descriptive research design. A sample of thirty (30) primary schools was randomly drawn from the population of a hundred and four (104) Primary schools located in the Local Government Area using stratified random sampling techniques (15 public and 15 private primary schools). Five (5) research questions and two null hypotheses were formulated to guide the study, while the main instrument designed for data collection was a Checklist or Inventory. The statistical analyses were done using simple statistics such as Mean, Percentages and t-test at 0.05 levels of significance. The analysis revealed a high level of readiness in terms of personnel, but infrastructurally, there have been a gross inadequacy in the provision. As such, it was therefore recommended among other things that, there is need for government at all levels, including the private sector and other donor agencies as well as all stake holders in the educational sector to provide the necessary personnel and basic infrastructure to facilitate meaningful implementation.
\end{abstract}

\section{Introduction}

Universal Basic Education (UBE) programme is a Federal Government's policy to bring education to the door steps of every Nigerian. Access to education should therefore not be a problem if it were properly implemented. The current UBE scheme in Nigeria can be said to be the product of earlier educational schemes, programmes and educational decisions, which is also the offshoot of previous schemes, which the current scheme is expected to offset. According to Ekefere (2000), educational activities of the 1950s laid the foundation stones for later educational developments in the 1960s and beyond. Nigeria educational system has witnessed a catalogue of changes in policies and programmes. In fact, many of these changes in educational policies in Nigeria have been described as the product of confusion (Ayeni, 2000). There is therefore, a high level of uncertainties, which is beclouding meaningful planning in Nigeria's educational system. This can be very dangerous particularly as the future of Nigeria and Nigerians will be determined by the level of education her nationals have acquired. Obanya (2000) also opined that, the universal basic education programme should be seen as part of Nigeria's attempt to rejoin the international community by giving effect to her commitment to the world trends in the field of basic education.

\section{The Concept of Universal Basic Education (UBE)}

The Concept of UBE as enunciated by the federal government of Nigeria was anchored upon the realization that education is not only an investment in human capital, but also a pre-requisite for economic development. Enoch and Okpede (2000), describes UBE as a form of education which is essential for life long. Similarly, Anyabolu (2000) sees it as a form of education that is meant to equip an individual with the necessary skills to survive in his environment, or learning that is needed to build from roots to literacy and innumeracy. Fabunmi (2004) considers UBE as early childhood, pre-primary, primary, junior secondary schools and basic functional literacy for out-of-school children, youth and adults. The Federal Ministry of Education (FME, 2000) defines UBE as the foundation for sustainable lifelong learning that provides reading, writing and numeracy skills. Furthermore, the National Policy on Education (FRN, 2004), basic education is the approved level of learning as already stated that, basic education shall be 9-year duration comprising 6 years of primary education and 3 years of junior secondary education, and that shall be free and compulsory. To Ajayi (2000), UBE means early childhood care and education those 9 years of formal schooling, adult literacy and non-formal education of special target groups such as Nomads, Migrant fishermen, Almajiris (Street children) and the Disabled.

Ogizi and Kohan (1981) opined that, UBE is an expanded vision comprising the universalizing of access and promotion of equity focusing on learning and enhancing the environment of learning and strengthening of partnership. Similarly, Eddy and Akpan (2009), basic education could be seen as the fundamental education, bottom line or foundation education upon which every other education whether formal, 
informal or non-formal, can be built and without which any educational structures erected will not have chances of success.

\section{Statement of the problem}

As a matter of policy, many states of the Federation not fully prepared for the take-off of the UBE programme or yet to meet up with the requirements of the Federal Ministry of Education and the Universal Basic Education Commission (UBEC), as specified in the World Bank Benchmark (Implementation guidelines). According to Ortyoyande (2000), for Universal Basic Education programme to survive there must be a planned and steady supply of personnel (teachers) and infrastructure both qualitatively and quantitatively. It is worrisome to note that the situation in Kebbi was yet to be determined, this prompted the researcher to embark on this study.

\section{Research Questions}

This study sought to answer the following research questions:

(i) To what extent are the personnel adequate for a successful UBE impementation in Birnin Kebbi LGA?

(ii) To what extent is provision made for the Re-training programmes to update teachers knowledge and skills at regular intervals?

(iii) To what extent are the necessary or basic infrastructural facilities adequate in both public and private primary schools?

(iv) To what extent is the proprietorship of schools a factor in the implementation of the UBE programme?

(v) To what extent does school location affect the level of their personnel and infrastructure in the implementation of the UBE programme?

\section{Research Design}

\section{Methodology}

For the purpose of this research, the researcher adopted a descriptive survey research design in carrying out the research work.

\section{Population and Sample}

The target population for this study comprised of all the one hundred and four (104) primary schools (both Public and Private) located in Birnin kebbi local government area. Adopting a stratified random sampling technique, a sample of thirty (30) primary schools were randomly drawn (ie, 15 public and 15 private primary schools), representing $31 \%$ of the total population.

\section{Instrumentation}

The instruments designed for data collection were the Checklist or Inventory and a Questionnaire titled "Teacher Training Programme Questionnaire" (TTPQ). Both instruments were designed and constructed based on the universal standards for establishing primary schools in Nigeria, which were also in accordance with the World Bank standards / Benchmark for the implementation of the UBE programme in Nigeria.

\section{Data Collection and Analysis}

In order to effectively administer the instruments developed for the study, the researcher visited each of the 30 sampled schools, after which, he employed the use of "TRANSECT WORK" ( i.e On-the-Spot assessment of both personnel and Infrastructural facilities present on ground as at the time of visit or assessment) Meanwhile, the data collected was presented in tables and analyzed using simple descriptive statistics such as Mean, Percentages, standard deviations and t-test for the research questions and hypothesis respectively.

Research question 1.

\section{Results and Discussion}

To what extent are the personnel adequate for a successful UBE implementation in Birnin Kebbi LGA? 
Table 1: Analysis to research question 1.

\begin{tabular}{|c|c|c|c|c|}
\hline \multirow[t]{2}{*}{ S/No. Names of school } & \multicolumn{2}{|c|}{ Recommended } & \multirow{2}{*}{$\begin{array}{l}\text { Percentage } \\
\text { ability }\end{array}$} & \multirow[t]{2}{*}{ Remarks } \\
\hline & $\begin{array}{l}\text { no of } \\
\text { teachers }\end{array}$ & $\begin{array}{l}\text { no of } \\
\text { teachers }\end{array}$ & & \\
\hline 1. Abubakar Gari Mallam model prim & $\operatorname{sch} 23$ & 20 & 87 & Adequate \\
\hline 2. Abubakar Nadaniya MPS & 21 & 19 & 90 & Adequate \\
\hline 3. Adamu Gulma MPS & 19 & 16 & 84 & Adequate \\
\hline 4.Army Children School & 29 & 25 & 86 & Adequate \\
\hline 5. Atiku Bagudu Scince Prim Sch. & 21 & 18 & 86 & Adequate \\
\hline 6. Baiti Model PrimarySchool & 26 & 24 & 92 & Adequate \\
\hline 7. Bayan Tasha MPS & 24 & 21 & 88 & Adequate \\
\hline 8. Buhari Bala MPS & 16 & 16 & 100 & Adequate \\
\hline 9. Dr. Yahaya Shantali MPS & 36 & 28 & 78 & Adequate \\
\hline 10. Gudi Takalau MPS & 21 & 17 & 81 & Adequate \\
\hline 11. Gwandu EmirateMPS & 26 & 20 & 77 & Adequate \\
\hline 12. Hajiya Kubura MPS & 23 & 19 & 90 & Adequate \\
\hline 13. Justice Ibrahim MPS & 40 & 33 & 83 & Adequate \\
\hline 14. Magaji Gari MPS & 25 & 23 & 92 & Adequate \\
\hline 15. Magaji Rafi Bello MPS & 21 & 20 & 95 & Adequate \\
\hline 16. ABI Private School & 09 & 09 & 100 & Adequate \\
\hline 17. Alheri Nursery \& Primary School & 07 & 06 & 86 & Adequate \\
\hline 18. Brilliance NPS & 11 & 11 & 100 & Adequate \\
\hline 19. Federal Staff School Gesse & 10 & 10 & 100 & Adequate \\
\hline 20. FOMWAN NPS & 11 & 10 & 100 & Adequate \\
\hline 21. Harmony NPS & 10 & 09 & 90 & Adequate \\
\hline 22. High Standard NPS & 13 & 13 & 100 & Adequate \\
\hline 23. Islamiya NPS & 08 & 06 & 75 & Adequate \\
\hline 24. JODA Int'l NPS & 12 & 12 & 100 & Adequate \\
\hline 25. NYSC NPS & 14 & 14 & 100 & Adequate \\
\hline 26. Progressive NPS & 06 & 06 & 100 & Adequate \\
\hline 27. Polytechnic Staff Sch & 17 & 17 & 100 & Adequate \\
\hline 28. Solid Science NPS & 15 & 15 & 100 & Adequate \\
\hline 29. St. Luke's NPS & 12 & 12 & 100 & Adequate \\
\hline 30. Ultimate NPS & 14 & 14 & 100 & Adequate \\
\hline
\end{tabular}

\section{- $\quad$ (MPS $=$ Model Primary Schools $)$}

Table 1 gives an average percentage of $89 \%$ of the recommended number of teachers. This shows an encouraging state of readiness in the public and private primary schools in terms of personnel requirement for UBE programme.

\section{Research question 2.}

To what extent is provision made for the Re-training programmes to update teacher's knowledge and skills at regular intervals?

Table 2: Analysis showing the Training/Sensitization programmes for UBE teachers in Birnin Kebbi LGA.

\begin{tabular}{|lccc|}
\hline S/No. & Training Programm & Teacher,s Attendance (\%) & Remarks \\
\hline 1. & Workshops & $78(26 \%)$ & Not adequate \\
2. & Seminar & Nil & Not organized \\
3. & Conference & Nil & Not organized \\
4. & Symposium & Nil & Not organized \\
\hline
\end{tabular}

Table 2 show that, Re-training/Sensitization programmes aimed at updating teacher's knowledge and skills in the implementation of the UBE programme in Birnin Kebbi LGA have not been seriously carried out. Out of the 300 sampled teachers from 30 selected schools, only 78 teachers have ever attended a workshop. This represents $26 \%$ of the entire population of teachers in the local government area.

\section{Research question 3}

To what extent are the necessary or basic infrastructural facilities adequate in both public and private primary schools? 
Universal Basic Education (Ube) Programme in Nigeria: Personnel and Infrastructural .....

Table 3: Analysis of availability and adequacy of basic infrastructural facilities in 30 sampled primary schools in Birnin Kebbi LGA.

\begin{tabular}{|lcccccc|}
\hline S/No Facilities & $\begin{array}{c}\text { Recommended } \\
\text { number in } \\
\text { public schools }\end{array}$ & $\begin{array}{l}\text { Recomm. } \\
\text { no. in } \\
\text { private } \\
\text { schools }\end{array}$ & $\begin{array}{l}\text { Total no } \\
\text { recomm. } \\
\text { in all } \\
\text { schools }\end{array}$ & $\begin{array}{l}\text { Available } \\
\text { no in } \\
\text { public } \\
\text { schools }\end{array}$ & $\begin{array}{l}\text { Available } \\
\text { no in } \\
\text { private } \\
\text { schools }\end{array}$ & $\begin{array}{c}\text { Total } \\
\text { availability } \\
\text { in all } \\
\text { schools }\end{array}$ \\
\hline 1. Classs rooms & 297 & 204 & 501 & 242 & 191 & 433 \\
2. Pupil's Furniture & 7,315 & 3,265 & 10,580 & 1,692 & 2,850 & 4,542 \\
3. Staff furniture & 416 & 214 & 630 & 114 & 201 & 315 \\
4. Staff room/Offices & 30 & 30 & 60 & 15 & 15 & 30 \\
5. Libraries & 15 & 15 & 30 & 03 & 08 & 11 \\
6. Labs/Workshops & 15 & 15 & 30 & 02 & 05 & 07 \\
7. Computer Labs & 15 & 15 & 30 & 03 & 12 & 15 \\
8. Toilets & 30 & 30 & 60 & 10 & 15 & 25 \\
9. Safe water Sources & 15 & 15 & 30 & 04 & 10 & 14 \\
10. Football fields & 15 & 15 & 30 & 15 & 06 & 21 \\
11. Lilos/Swings & 15 & 15 & 30 & 04 & 14 & 18 \\
12. Slides & 15 & 15 & 30 & 02 & 12 & 14 \\
13. First Aids Kits & 15 & 15 & 30 & 03 & 15 & 18 \\
14. Television sets & 15 & 15 & 30 & 01 & 07 & 08 \\
\hline
\end{tabular}

$\mathrm{X} 1$ (mean requirement $)=808.7 \quad \mathrm{X} 2($ mean availability $)=366.2$

Percentage availability $=45 \%$

Table 3 analysis has clearly revealed the inadequacy in the provision of the basic infrastructural facilities in those primary schools, as it has been shown in the mean requirement of 808.7 at against mean availability of 366.2 .

Research Question Four

To what extent does the Proprietorship of schools a factor in the implementation of the UBE programme?

Table 4: Analysis of the effects of proprietorship on Personnel and Infrastructure.

\begin{tabular}{|lcccccc|}
\hline S/No Item & $\begin{array}{l}\text { Required } \\
\text { no in } \\
\text { public } \\
\text { schools }\end{array}$ & $\begin{array}{l}\text { Available } \\
\text { no in } \\
\text { public } \\
\text { schools }\end{array}$ & $\begin{array}{l}\text { percentage } \\
\text { av) } \\
\text { availability }\end{array}$ & $\begin{array}{l}\text { Required } \\
\text { no in } \\
\text { private } \\
\text { schools }\end{array}$ & $\begin{array}{l}\text { Avail. } \\
\text { no in } \\
\text { private } \\
\text { schools }\end{array}$ & $\begin{array}{c}\text { percentage } \\
\text { (\%) } \\
\text { Avail. }\end{array}$ \\
\hline 1. Personnel & 371 & 319 & 86 & 169 & 164 & 97 \\
2. Infrastructure & 8,238 & 2,119 & 26 & 3,893 & 3,376 & 87 \\
\multicolumn{1}{r}{ Total } & $\mathbf{8 , 6 0 9}$ & $\mathbf{2 , 4 3 8}$ & $\mathbf{5 6}$ & $\mathbf{4 , 0 6 2}$ & $\mathbf{3 , 5 4 0}$ & $\mathbf{9 2}$ \\
\hline
\end{tabular}

Results of the findings from this table reveal a higher percentage availability of $97 \%$ Personnel in private primary schools as at against $86 \%$ in the public schools. The analysis also shows a high percentage level of basic infrastructural facilities of $86 \%$, whereas, alowpercentage rate of $26 \%$ was found in public schools

Research Question four.

To what extent does school location affect the level of their personnel and infrastructure in the implementation of the UBE programme?

Table 4: Analysis of personnel and Infrastructural facilities in the sampled 22 Urban and 08 Rural primary schools in Birnin Kebbi LGA.

\begin{tabular}{|lccccccc|}
\hline S/No Items & $\begin{array}{l}\text { Required } \\
\text { in urban } \\
\text { schools }\end{array}$ & $\begin{array}{l}\text { Available } \\
\text { in urban } \\
\text { schools }\end{array}$ & $\begin{array}{c}\text { percentage } \\
\text { (\%) } \\
\text { availability }\end{array}$ & $\begin{array}{l}\text { Required } \\
\text { in rural } \\
\text { schools }\end{array}$ & $\begin{array}{l}\text { Available } \\
\text { in rural } \\
\text { schools }\end{array}$ & $\begin{array}{c}\text { Percentage } \\
\text { (\%) } \\
\text { availability }\end{array}$ \\
\hline 1. & Personnel & 418 & 376 & 90 & 122 & 107 & 88 \\
2 & .Infrastructure & 416 & 333 & 80 & 124 & 112 & 90 \\
& Total & $\mathbf{8 3 4}$ & $\mathbf{7 0 9}$ & $\mathbf{8 5}$ & $\mathbf{2 4 6}$ & $\mathbf{2 1 9}$ & $\mathbf{8 9}$ \\
\hline
\end{tabular}

Table 4 has shown that there no significance difference in readiness (availability) of personnel and infrastructural facilities in the rural primary schools than those schools located in the urban areas. It therefore means that location of schools has no effect on the level of their personnel and infrastructure in the implementation of UBE programme.

Hypotheses Testing.

Ho1: There is no significant difference between personnel and infrastructural readiness in public and private primary schools for UBE implementation. 
Universal Basic Education (Ube) Programme in Nigeria: Personnel and Infrastructural .....

To what extent does school location affect the level of their personnel and infrastructure in the implementation of the UBE programme?

Table 5: Mean, Standard Deviation and t-test analysis to Hypothesis 1.

\begin{tabular}{|c|c|c|c|c|c|c|c|c|}
\hline $\mathbf{S} / \mathbf{N}$ & Proprietorship & $\begin{array}{c}\text { No of } \\
\text { Schools }\end{array}$ & Mean & S.D & & df & t-cal & t-tab \\
\hline \multirow[t]{2}{*}{1.} & $\begin{array}{l}\text { Public } \\
\end{array}$ & 15 & 186.53 & 2611.47 & & & & \\
\hline & & & & & 28 & 0.01 & 1.07 & \\
\hline 2. & Private & 15 & 185.07 & 2590.93 & & & & \\
\hline
\end{tabular}

$\mathrm{P}=0.05$ level of significance, $\mathrm{df}=$ degree of freedom $(28), \mathrm{t}-\mathrm{tab}=$ tabulated value of $\mathrm{t}(1.70)>\mathrm{t}-\mathrm{cal}=$ Calculated value of $t(0.01)$.

From the analysis in table 5, it has shown that there is no significance difference between personnel and infrastructural readiness in public and private primary schools in the implementation of the UBE, since the tabulated t-value of 1.70 is greater than the calculated

t-value of 0.01 , at $5 \%$ level of significance with 28 degree of freedom. The null hypothesis is therefore accepted.

Ho2: There is no significant difference between urban and rural primary School level of readiness in the implementation of the UBE programme

Table 6: Mean, Standard deviation and t-test analysis of hypothesis 2.

\begin{tabular}{|lllllllll|}
\hline S/N & Location & No of schools & Mean & S.D & df & t-cal & t-tab \\
\hline 1. & Urban & 22 & 32.82 & 26.25 & & & \\
& & & & & 28 & 0.12 & 1.70 \\
& & & & & & & & \\
2. & Rural & 08 & 26.05 & 11.64 & & & \\
\hline
\end{tabular}

$\mathrm{P}=0.05$ level of significance, $\mathrm{df}=$ degrees of freedom $(28), \mathrm{t}$-tabulated $(1.07)>\mathrm{t}$-calculated $(0.12)$

From table 8 , it can be deduced that there is no significance difference between the urban and rural primary schools in readiness in the implementation of the UBE programme in Birnin kebbi local government area since the tabulated $t$-value of 1.07 is greater than the calculated t-value of 0.12 at 0.005 levels of significance with 28 degrees of freeedom, the null hypothesis therefore not rejected.

\section{Discussion of Findings}

Findings from the first research question has shown how far Government have recruited teachers adequately both in quantity and quality, as proposed in the implementation blue prints (FME, 2000). It is also confirmed that only qualified teachers were recruited unlike the case of the private schools where both the qualified (trained) and unqualified (untrained) are recruited.

Analysis from table 2 reveals that $82.3 \%$ of the recommended number of teachers in Birnin kebbi local government area was recruited in preparation to the implementation. This shows an encouraging state of readiness in the implementation of the programme. However, the findings seems to be conflicting with the earlier findings of Eddy and Akpan (2009) which shows that there is a high level of inadequacy in the provision of personnel for a successful UBE implementation in most states of the Federation.

To the third research question, the study reveals the extent to which the infrastructures are provided in both the private and public primary schools to be inadequate both in quality and quantity, especially in the public primary schools as stipulated in the KSUBEB (2000). The findings are therefore corroborated by those of Adepoju and Fabiyi (2006), Adebola (2007), Ogonor and Osunde (2007) and Danjuma (2007) whose findings reveals that there is a gross inadequacy in the provision of infrastructural facilities in the implementation of the UBE programme in Nigeria.

Table 4 analysis reveals the extent to which proprietorship of schools could be considered a factor in the implementation of the UBE programme. To some extent, the percentage availability of personnel in the private schools was found to be $97 \%$ which is greater than that of public primary schools, which is $86 \%$. the table also shows that interms of infrastructure, the private schools have a higher percentage of $87 \%$ as against $26 \%$ in public schools. 


\section{Recommendations}

Based on the findings of this study, the following recommendations among others were proffered or put forward for a better implementation, and to make the UBE programme in Kebbi state in particular and Nigeria at large more effective and successful.

1. That government at all levels including the private sectors to intensify efforts in the provision of both qualified and required number of personnel, as well as the basic infrastructural facilities.

2. That attention should be given to or focused on schools located in the rural areas also.

3. Training/Sensitization programmes should always be organized at regular intervals to update teachers knowledge, skills and inform them of new existing knowledge in educational sector

\section{Conclusion}

Based on the findings of this research work, conclusion was therefore drawn that, Birnin kebbi Local government is readily equipped with enough personnel (teachers) who are the principal implementers/ executors of the universal basic education programme. However, in terms of infrastructure, more efforts has to be intensified to ensure that the right quantity and quality of both personnel and infrastructure is been met, in accordance with the implementation guide lines.

\section{References}

[1]. Adebola, O.J. (2007). Perceived Impact of Universal Basic Education on National Development in Nigeria. International Journal of African andAfrican Studies, 6(1):56-62, January.

[2]. Adepoju, A. \& Fabiyi, A. (2006). Universal Basic Education: Challenges and Prospect; Retrieved on $15^{\text {th }}$ December, 2008 from http://www.informworld.

[3]. Eddy, E.N. \& Akpan, M.E. (2009). The Prospect of UBE Programme in Akwa Ibom State, South-South Nigeria; International NGO Journal.4(2):46-49

[4]. Retrieved on $3^{\text {rd }}$ March, 2009 from http://www.academiciournals.org/INGOJ

[5]. Ajayi, K. (2000). Universal Basic Education (UBE) Scheme: "Matters Arising". Convocation Lecture delivered at the $31^{\text {st }}$ Convocation Ceremony of Federal College of Education (Technical), Akoka, Yaba Lagos. April.

[6]. Anyabolo, E.I. (2000). Basic Education for Productivity and Enhancement on National Economy. Journal of Vocational, Technical and Adult Education. Nnamdi Azikiwe University (UNIZIK), Awka, Nigeria. 6(2),9-11.

[7]. Ayeni, M.A. (2000). Secondary Education: A New Look at Nigerian Adolescents and Young Adults. A Paper Presented at the 18 Annual Conference of Philosophy of Education Association of Nigeria, 16-18 October.

[8]. Danjuma, Y. (2007). Situational Analysis of Universal Basic Education in some selected schools in Lapai Local Government Area of Niger State. Unpublished PGDE Project, National Teacher's Institute, Kaduna.

[9]. Eddy, E.N. \& Akpan, M.E. (2009). The Prospect of UBE Programme in Akwa-Ibom State, South-South Nigeria; International NGO Journal. 4(2):46-49. Retrieved on $3^{\text {rd }}$ March, 2009 from http//www.academicjournals.org/INGOJ.

[10]. Ekefere, O. (2000). Effective Funding Arrangement to Ensure UBE Success. Paper Presented at the UBE Local Level Dialogues held at Makurdi.

[11]. Enoch, E.O. \& Okpede, E.O. (2000). The Meaning, History, Philosophy and Lessons of UBE Proceedings of the 15 ${ }^{\text {th }}$ Annual Congress of the Nigerian Academy of Education.

[12]. University of Benin; 6-9 $9^{\text {th }}$ November (eds.). aghenta, J.A. and Awambor, D., Benin City: Anbik Press.

[13]. Fabunmi, M. (2004). The Relevance of Universal Basic Education to National Development: A Planner's Perspective. Ibadan: Awemark Industrial Printers.

[14]. Federal Ministry of Education (FME). (2000). Implementation Guidelines for the Universal Basic Education (UBE) Programme, FMOE, Abuja.

[15]. Federal Republic of Nigeria (2004). National Policy on Education. Lagos: FGN Press.

[16]. Kebbi State Universal Basic Education Board (KSUBEB) (2000). Preliminary Ideas for UBE Takeoff in Kebbi state. Presentation at the Abuja SPEB Meeting; April.

[17]. Obanya, P. (2000). National Press Briefing on the Universal Basic Education (UBE) Programme. Lagos: State Ministry of Education.

[18]. Ogonor, B.O.\& Osunde, A.U. (2007). The Universal Basic Education Programme and Female Trafficking in South-South, Nigeria. International Journal of Lifelong Education. 26(4), 602-607. Retrieved on February 2009 from http//www.eric.ed.gov.'ERICwebportal/custom/portlets/record/details/detailmini.Jsp?

[19]. Ortyoyande, J.H. (2000). The Financial and Manpower Implications of Educational Planning for all by the Year 2000. Journal of Teacher Education and Teaching. 3(2),15-17. Ekpoma : Ambrose Ali University Press Ltd.

[20]. Ogizi, P. \& Kohan, H. (1981). The Role of Parents in the Implementation of the Universal Basic Education in Nigeria: Journal of Counselling Association of Nigeria. 18(2), 48-56, August. 